\title{
Intangible Assets Finance: A Complementary or Substitution Effect between External and Internal Channels? Evidence from the Italian Divide
}

\author{
Marianna Succurro ${ }^{1}$ \\ ${ }^{1}$ Department of Economics, Statistics and Finance, University of Calabria, Italy \\ Correspondence: Marianna Succurro, Department of Economics, Statistics and Finance, Cubo 0/C, University of \\ Calabria, 87036 Rende (CS), Italy. Tel: 39-0984-492-445. E-mail: m.succurro@unical.it
}

Received: October 11, 2014

2014doi:10.5539/ijef.v6n12p1

Accepted: October 27, $2014 \quad$ Online Published: November 25, URL: http://dx.doi.org/10.5539/ijef.v6n12p1

\begin{abstract}
The goal of this research is to verify whether, and to what extent, differences in the availability of both internal and external financial resources explain differences in intangible capital between the Centre-North and the South of Italy. The paper focuses on Italian manufacturing firms over the 2003-2010 period. The empirical evidence, based on a dynamic econometric model, shows that the effects of finance on intangible capital can be heterogeneous depending on firms' relative size and geographic location. In the Centre-North, where access to financial markets is easier, firms rely on external funding to invest in intangible assets. By contrast, in Southern regions, where access to external finance is harder, firms invest in intangible capital by substituting external funds with internal resources. The empirical evidence suggests that below a certain level of per-capita GDP a substitution effect prevails between the two sources of finance. On the contrary, some complementary effect between external and internal finance would exist in more developed Italian regions.
\end{abstract}

Keywords: external finance, internal finance, intangible capital, Italian divide

\section{Introduction}

Intangible assets are particularly important for today's knowledge-based economy. The role of intangibles as value and growth creators, indeed, is accepted among economists, investors and managers. The investment in intangible capital includes expenditures for human capital, in the form of education and training, public and private scientific research, and business expenditures for product research and development, market development, and organizational and management efficiency.

Thus, intangible assets are a principal driver of firms' competitiveness (Lev, 2001; Nakamura, 2001), but they also increase opportunities for workers and significantly affect labor productivity, economic growth and, in turn, the economic well-being of both local communities and nations (Marrocu et al., 2011; National Research Council, 2009; Corrado et al., 2009; Corrado et al., 2006). These are strategic investments in the long-run growth path of individual companies and of the economy as a whole. For this reason, intangibles are increasingly seen by policy makers as essential for the sustained economic health of the economy. Intangible assets comprise a subset of services which accounts for three-quarters of all economic activity (National Research Council, 2009). According to several analysis, investment in intangible assets exceed all investment in tangible property and, if properly accounted for, would raise measured productivity growth significantly.

For this reason, a first group of studies examine and propose appropriate measurements of intangibles. One of the goals of studies in this field is to unlock the hidden value found in intangible assets through the techniques of finance. Despite recent developments, several intangible assets are not reported by companies and, in the national economic accounts, they are treated as expenses rather than investments. At the moment, the definition of intangible capital is controversial and there is no coordinated national strategy for promoting intangible investments (Stolowy \& Jany-Cazavan, 2001; Wyatt, 2005; Siegel \& Borgia, 2007; Marrocu et al., 2011). Also the European Union aims at adopting effective strategies towards this objective.

A second group of researches aims to measure how firm performance correlates with intangible assets management and discuss microeconomic and macroeconomic implications of intangibles and their role in global economies. More specifically, these studies analyze a range of policy-relevant topics such as how intangibles are 
created and used by firms, how intangibles contribute to growth, the variety and scale of emerging markets in intangibles, what the governments' role should be in supporting markets and promoting investments in intangibles (Corrado et al., 2006; Corrado et al., 2009).

This paper assesses how the intangible capital depends on the various sources of finance and whether it varies across the Italian regions by focusing on Italian manufacturing firms over the 2003-2010 period. It relates to at least two strands of literature: that on the impact of finance on investment in intangible assets and that on the Italian divide.

With reference to the first strand of researches, it is well known that intangible assets need financing, often at a very early stage, and that the source of finance is particularly important for investments in the creation of knowledge because of high firm specific investment costs and low collateral value (Williamson, 1988; Shleifer \& Vishny, 1992; Holthausen \& Watts, 2001; Arrow, 1962; Nelson, 1959). Besides information asymmetries, the intangibility of the potential asset may make raising funds externally more costly for intangible assets than for other types of investments.

With reference to the second strand of literature, several studies analyze the origins and the nature of the dualism of the Italian economy, mainly concerning the reasons of regional differences in per capita GDP in Italy (Aiello \& Cardamone, 2012; Aiello \& Scoppa, 2000; Di Liberto et al., 2008; Maffezzoli, 2006), the process of convergence across Italian regions (Carmeci \& Mauro, 2002; Paci \& Pigliaru, 1995; Paci \& Saba, 1998; Bianchi \& Menegatti, 1997; Fabiani \& Pellegrini, 1997) and additional explanations for the Italian divide. This last group of studies pays attention to the quality of institutions, the level and the quality of infrastructure, the level of trust and cooperation, the role of public capital and social capital, the agglomeration economies and the functioning of financial market (Bigoni et al., 2013; Iammarino et al., 2009; Di Giacinto \& Nuzzo, 2006; Atzeni \& Carboni, 2006; De Stefanis \& Sena, 2005; Evangelista et al., 2002). Some recent innovation studies suggest that differences in regional innovative activities are one of the most important factors explaining convergence and divergence in economic performance at regional level (for a review and some stylized facts, see Feldman \& Kogler, 2010). It is also a commonplace that firms located in Southern regions are riskier, more subject to credit constraints and have less access to the capital market (Iazzolino \& Succurro, 2012; Sarno, 2008; Sarno, 2007; Giannola \& Marani, 1991). In this context, this paper contributes to an explanation of the Italian regional divide by evaluating the impact of diverse sources of funding on intangible assets at firm-level. Some new estimates are provided for the empirical relationship between the source of funding and intangible capital across the main Italian geographical areas.

Empirical evidence shows that the effects of finance on innovation can be very different depending on firms' relative size and geographic location. In the Centre-North, where access to financial markets is easier, firms rely on external finance to undertake investment in intangibles. By contrast, in Southern regions, where access to external finance is harder, firms invest in intangible assets by substituting external finance with internal funding. Data suggest some complementary effect between the two sources of finance and intangible assets for manufacturing firms operating in the Centre-North of the country, while the interaction term indicates some substitution effect when the South of Italy is considered.

The paper is organized as follows. Section 2.1 gives some preliminary definitions and descriptive statistics, Section 2.2 presents the econometric specification and Section 3 shows the empirical evidence on the impact of sources of finance on intangible activities. Section 4 provides some discussion and concluding remarks.

\section{Method}

This study is mainly based on firms' accounting data taken from the Amadeus database, published by Bureau van Dijk. It is a European financial database which includes more than 4 million firms' accounting data in a standardized balance sheet format. The database includes both SME and large companies operating in all industries. The research consists of a descriptive part and an econometric analysis, reported below.

\subsection{Definition of Variables and Descriptive Statistics}

Like any type of investment, a firm's investment in intangible assets strongly depend on the availability of financial resources (Czarnitzi \& Hottenrott, 2011; Brown et al., 2009; Benfratello et al., 2008; Sarno, 2008; Sarno, 2007; Ughetto, 2008; Guiso et al., 2004; Giudici \& Paleari, 2000; Himmelberg \& Petersen, 1994; Hall, 1992; Hall, 1990). In presence of strong external financial constraints, internal sources of finance become an important channel for intangible capital. Indeed, in principle, there are two sources for financing innovation projects: external financial sources, such as bank loans, other debt contracts and trade credit, and internal sources, such as cash flow. 
Thus, in the following empirical analysis, we consider both firms' external and internal funds and evaluate their impact on intangibles. By external financing we mean funds not generated internally (not self-financing). More specifically, we measure external finance $(E X T F)$ as the ratio between bank loans, long term debt and trade credit to total assets. We measure the availability of internal funds (INTF) as the ratio between cash flow and total assets.

Intangible assets are heterogeneous since they include computer software, research and development expenditure, intellectual property, but also workforce training, spending to raise the efficiency and brand identification of firms. However, previous studies attempt to identify some categories of intangible capital: human capital, which includes all the talent, competencies and experience of firms' employees and managers; relationship capital, which includes organizational brand and reputation, and all key external relationships that drive firms' business, with customers, suppliers, partners, outsourcing and financing partners; structural capital, which includes recorded knowledge, processes, software and intellectual property; strategic capital which holds the whole system together. This last category includes culture, business model and external factors.

Table 1. Intangible assets

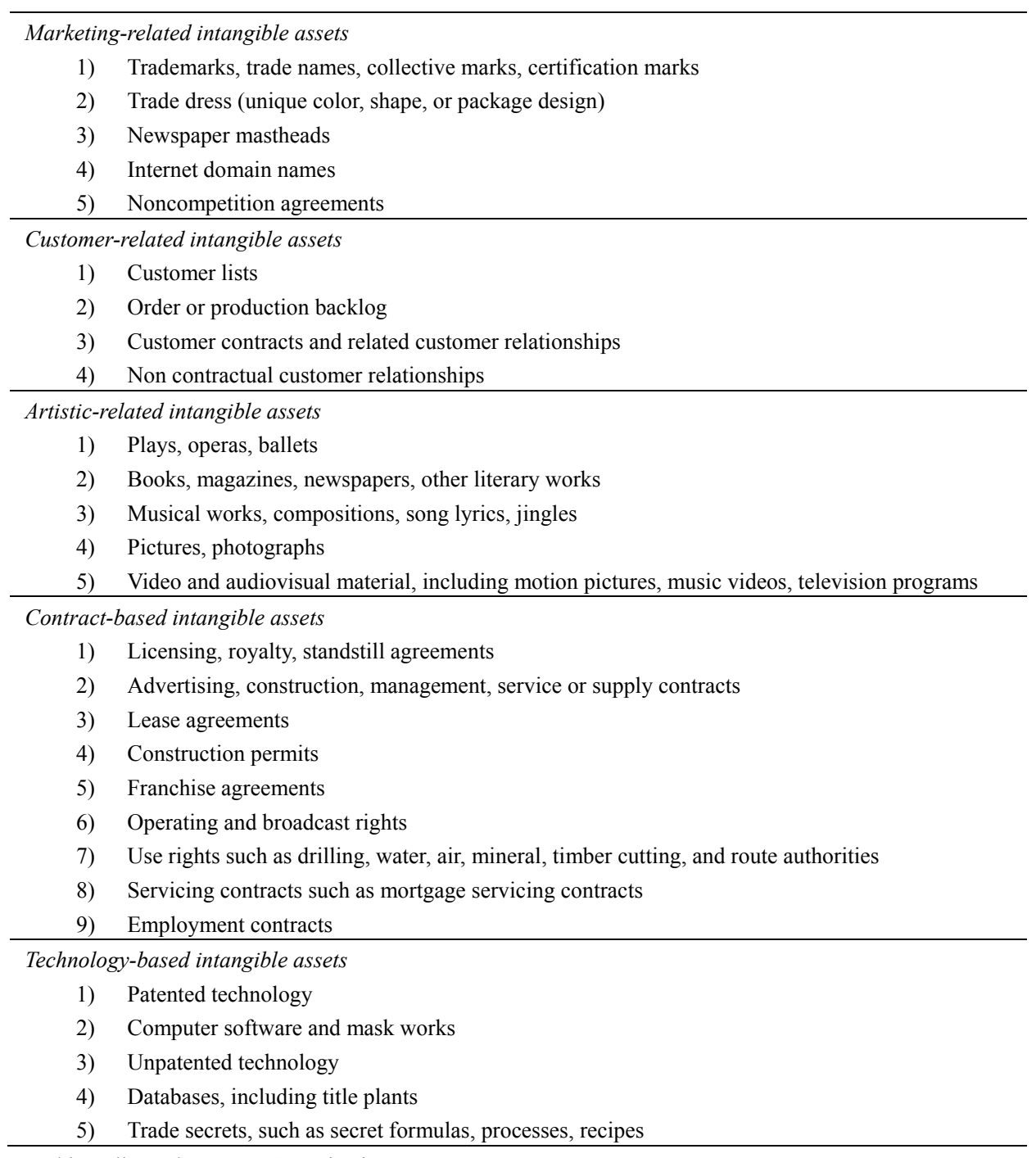
Source: WIPO, World Intellectual Property Organization.

In order to outline intangible capital, Table 1 illustrates a more detailed description of intangible assets distinguished in marketing-related intangible assets, customer-related intangible assets, artistic-related intangible assets, contract-based intangible assets and technology-based intangible assets. The composition of a firm's intangible assets varies a lot depending on the sector/region in which the firm operates, as well as on its relative 
size. However, there is a large consensus on the growing role played by intangible assets on firms' performance, especially in the industrialized countries where competition is based on inventions of new processes and products, improvements in employee skills and product image, high quality customer services and customer attraction (brands and relationship building).

In this study, intangible capital $(I A)$ is interpreted as all the knowledge assets of an organization and is measured as the ratio between intangible assets and total assets. Following previous studies (Bloch, 2005; Brown \& Petersen, 2009), we scale intangible assets by the book value of total assets.

Figure 1 shows the annual percentage variation of the mentioned ratios between 2003 and 2010. The ratio of external funds to total assets increases by $50.35 \%$ between 2004 and 2005 period and by $10 \%$ between 2005 and 2007 , then declines, with the sharpest fall $(7.68 \%)$ in the year following the international financial crisis. In the two years following the crisis the ratio of cash flow to total assets decreases even more sharply $(18.65 \%)$. Nevertheless, intangible assets over total assets shows a moderate positive trend over the analyzed period, with a higher annual percentage variations over the years following the financial crisis. The graph would also confirm the increasing role of intangible capital over total assets.

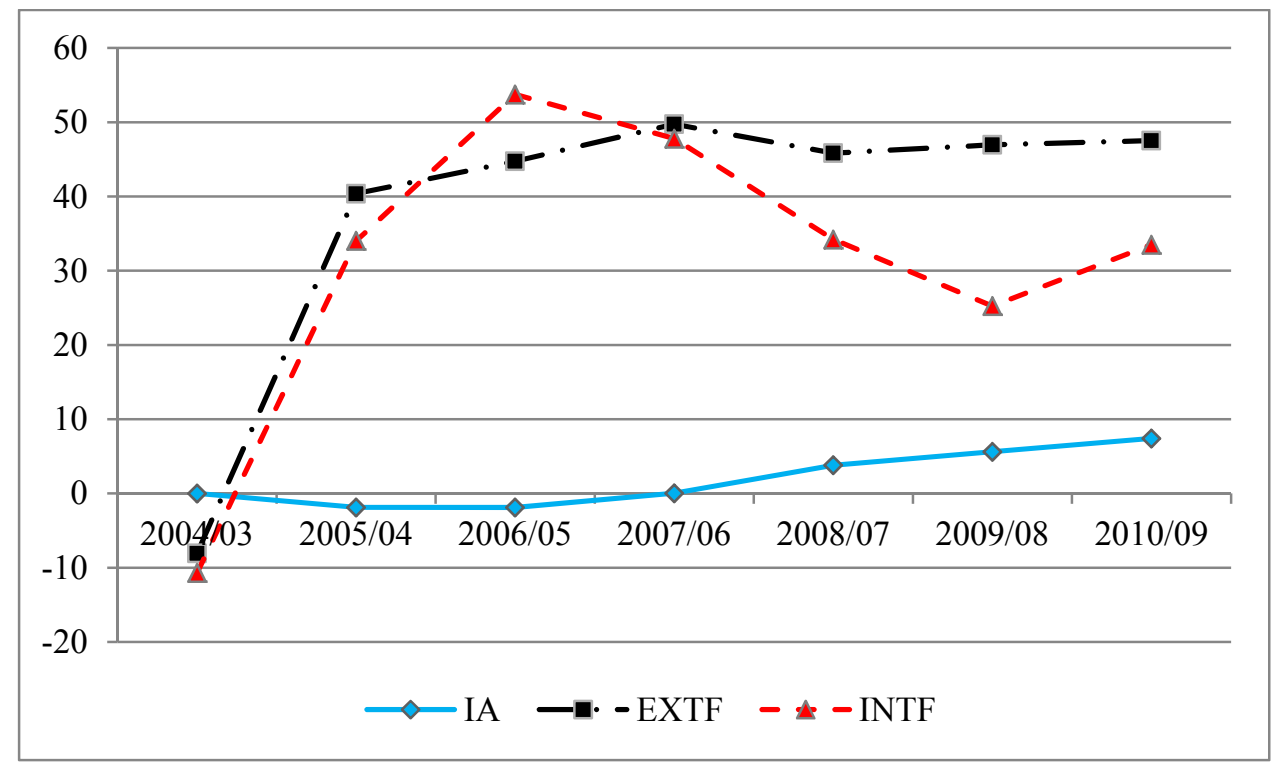

Figure 1. Intangibles, external and internal finance (annual percentage variation)

Note. Source: Own elaborations on Amadeus Database.

Table 2. Descriptive statistics

\begin{tabular}{llllll}
\hline \multicolumn{2}{l}{ Centre-North } & \multicolumn{2}{l}{ Min } & Max & Observations \\
\hline IA & 0.018542 & 0.0294549 & 0 & 0.3310969 & $\mathrm{n}=211824$ \\
EXTF & 0.4290595 & 0.2729609 & 0 & 3.513934 & $\mathrm{n}=211824$ \\
INTF & 0.056069 & 0.0457557 & -0.0593013 & 0.191428 & $\mathrm{n}=211824$ \\
Size & 14927.16 & 122467.7 & 2000.01 & $2.17 \mathrm{e}+07$ & $\mathrm{n}=211824$ \\
Age & 23.31891 & 17.66641 & 0 & 111 & $\mathrm{n}=211380$ \\
\hline South & & & & & \\
& Mean & Std. Dev. & Min & Max & Observations \\
\hline IA & 0.0150075 & 0.0258458 & 0 & 0.3034656 & $\mathrm{n}=22752$ \\
EXTF & 0.4252521 & 0.2651125 & 0 & 1.478869 & $\mathrm{n}=22752$ \\
INTF & 0.048743 & 0.0395275 & -0.0592883 & 0.1913708 & $\mathrm{n}=22752$ \\
Size & 10210.38 & 53002.63 & 2000.11 & 2950368 & $\mathrm{n}=22752$ \\
Age & 18.47402 & 14.91095 & 0 & 106 & $\mathrm{n}=22710$ \\
\hline
\end{tabular}

Source: Own elaborations on Amadeus Database. 
Table 2 illustrates the main variables and their descriptive statistics for all the Italian manufacturing firms included in the analysis by distinguishing between the Centre-North and the South of the country. Size is expressed in terms of total turnover (thousands euros) because this accounting variable is considered more reliable than the total number of employees reported in the balance sheets. On average, firms operating in the Centre-North are relatively larger and older than firms operating in Southern regions.

To identify possible regional differences, Table 3 illustrates the ratio of intangibles to total assets and both external and internal financial resources to total assets by region.

The data on intangible capital and internal funds show a certain degree of uniformity among the Italian regions although, on average, firms in the Centre-North are characterized by greater intangible assets $(1.85 \%)$ and cash flow $(5.2 \%)$ than those operating in the South $(1.60 \%$ and $4.8 \%$ respectively). With reference to external finance, however, the data show greater regional heterogeneity. On average, Southern manufacturing firms face greater difficulties in accessing external finance than those operating in the Centre-North, and EXTF may vary substantially even between regions in the same geographical area. Within the South, it varies between $16.21 \%$ in Basilicata and $19.62 \%$ in Sardinia, while within the Centre-North it ranges from $16 \%$ in Lazio to $22 \%$ in Umbria.

Table 3. Intangibles and financial resources by region (2003-2010, ave. \% values)

\begin{tabular}{lrrr}
\hline & $I A$ & EXTF & INTF \\
\hline SOUTH & 1.60 & 16.59 & 4.83 \\
Basilicata & 2.14 & 16.21 & 4.91 \\
Calabria & 1.77 & 16.97 & 5.22 \\
Campania & 1.50 & 16.88 & 4.79 \\
Puglia & 1.55 & 17.88 & 4.77 \\
Sardinia & 1.38 & 19.62 & 4.61 \\
Sicily & 1.23 & 17.96 & 4.72 \\
\hline CENTRE-NORTH & 1.85 & 18.32 & 5.21 \\
Abruzzo & 1.55 & 18.32 & 4.67 \\
Emilia Romagna & 1.76 & 17.48 & 5.43 \\
Friuli V.G. & 1.78 & 21.23 & 5.43 \\
Lazio & 1.94 & 15.98 & 5.08 \\
Liguria & 1.93 & 17.62 & 5.5 \\
Lombardy & 1.91 & 17.41 & 5.41 \\
Marche & 1.89 & 18.59 & 5.19 \\
Molise & 1.99 & 16.43 & 4.79 \\
Piedmont & 1.74 & 18.45 & 5.44 \\
Tuscany & 1.92 & 18.3 & 4.75 \\
Trentino & 1.74 & 17.99 & 5.89 \\
Umbria & 1.69 & 22.11 & 4.91 \\
Valle d'Aosta & 2.18 & 19.08 & 4.89 \\
Veneto & 1.88 & 18.44 & 5.57 \\
\hline
\end{tabular}

Source: Own elaborations on Amadeus Database.

As preliminary investigation, the correlation between intangibles and finance is analyzed by considering the mentioned ratios for all the Italian manufacturing firms as a whole (Table 4). The correlation coefficient between external finance and intangible capital is generally positive and significant at $1 \%$ level, but it is relatively higher in the Centre-North than in the South of the country. Also the correlation coefficient between internal funds and intangibles is positive and statistically significant at $1 \%$ level, but in this case it assumes a higher value for the South of the country.

Finally, external and internal funds show a negative and significant correlation in both geographical areas. The two finance channels, indeed, are not independent since serving debt reduces cash flow for future investments (Hall, 1990; Hall, 2002). 
Table 4. Matrix of correlations between intangibles and financial channels

\begin{tabular}{llll}
\hline Centre-North & & \\
IA & IA & EXTF & INTF \\
EXTF & $0.0850 * * *$ & 1.0000 & \\
INTF & $0.0289 * * *$ & $-0.1542 * * *$ & 1.0000 \\
\hline South & & & INTF \\
IA & IA & EXTF & \\
EXTF & 1.0000 & 1.0000 & 1.0000 \\
\hline
\end{tabular}

Note. Pairwise correlations significante levels: *10\%; **5\%;***1\%.

Source: Own elaborations on Amadeus Database.

\subsection{Econometric Specification}

The goal of the research is to verify whether, and to what extent, differences in the availability of both internal and external financial resources explain differences in intangible activity. The regression takes the form:

$$
I A_{i t}=\beta_{0}+\beta_{1} E X T F_{i t}+\beta_{2} I N T F_{i t}+\beta_{3} I N T E R_{i t}+\beta_{4} \text { Size }_{i t}+\beta_{5} \text { Age }_{i t}+\beta_{6} W_{i t}+\gamma_{t}+u_{i}+\varepsilon_{i t}
$$

where $i$ indicates firms, observed over the 2003-2010 period;

$\gamma_{t}$ indicates time effects, $u_{i}$ indicates firms' effects and $\varepsilon_{i t}$ are the stochastic residuals.

The dependent variable $I A$ indicates the firms' intangible activity and it is given by the ratio between intangible assets to total assets.

The variables EXTF and INTF indicate firms' external and internal financial resources respectively. As mentioned before, EXTF is built up as the ratio between long term debt, loans and trade credit to total assets and it indicates external financing; INTF, which indicates internal funds, is given by the ratio between cash flow and total assets.

The INTER variable indicates the interaction term $\left(E X T F^{*} I N T F\right)$ between internal and external finance (Note 1). Thus, we obtain:

$$
\begin{aligned}
& \frac{\partial I A_{i t}}{\partial E X T F_{i t}}=\beta_{1}+\beta_{3} I N T F_{i t} \\
& \frac{\partial I A_{i t}}{\partial I N T F_{i t}}=\beta_{2}+\beta_{3} E X T F_{i t}
\end{aligned}
$$

We merely check the sign and significance of the interaction term between internal and external finance: if it is positive, the two types of financial channels are considered complements in generating intangible activity; if it is negative, they are considered substitute.

The model (1) also includes firm-level variables like size and age.

Size of the firm is measured in terms of annual turnover which allows to split the sample on the basis of the threshold values reported in the Commission Recommendation 96/280/EC (updated in 2003/361/EC of May 6, 2003): small firms ( $€ 2 \mathrm{mln}<$ turnover $<€ 10 \mathrm{mln}$ ); medium-sized firms ( $€ 10 \mathrm{mln}<$ turnover $<€ 50 \mathrm{mln})$; large firms (turnover $>€ 50 \mathrm{mln}$ ) (Note 2).

Age, measured as the difference between the last available year and the foundation year of the company.

The $\mathrm{W}$ matrix considers additional industry-level and relevant region-level controls, reported below.

$C_{4}$ is a traditional structural measure of market concentration based on market shares and it has been included to take account of market power. In general, a $C_{m}$ concentration ratio is defined as the percentage of market share held by the largest $m$ firms in an industry:

$$
C_{m}=\sum_{i=1}^{m} s_{i}
$$

where $\mathrm{s}_{\mathrm{i}}$ is the market share and $m$ defines the $\mathrm{i}^{\text {th }}$ firm. This study includes the concentration ratio $\mathrm{C}_{4}$ which measures the total market share of the four largest firms in each manufacturing sector included in the analysis and it is comparable from sector to sector. The analysis considers the 23 manufacturing sectors with codes from 10 to 32 following the NACE Rev.2 primary codes. 
Region-level controls include:

$H K$, a measure of human capital calculated as the number of people with a scientific degree over 1000 residents aged 20-29 (source: Istat);

$G D P$, the per-capita gross domestic product (source: Istat);

Infr , a proxy of public infrastructures computed as kilometers of highway network in each region (over $1000 \mathrm{~km}^{2}$ of regional territory) (source: Istat);

Criminality, a proxy of social cohesion. It is computed as the number of people denounced for crimes (over 100000 inhabitants) (source: Istat).

\section{Results}

This paragraph illustrates the main empirical results for all Italian manufacturing firms included in the analysis (Table 5), for the Centre-North (Table 6) and the South (Table 7) of the country respectively.

The observations with missing values in the explanatory variables are dropped and, in order to correct for significant outliers, all observations in the lowest and in the highest $5 \%$ percentiles are eliminated.

To evaluate statistical significance of the model, several statistical tests are considered. Wald-tests estimates the overall (global) fit of the linear regression model. The Wald test null hypothesis that all the coefficients are jointly equal to zero is always rejected at $1 \%$ level.

Note that the pooled cross-section specification might generate biased and inconsistent results, since it does not take into account unobserved heterogeneity among firms like managerial ability, degree of risk-aversion, ownership structure, etc. In all the relevant specifications, indeed, the Breusch-Pagan test, not reported but available on request, indicates that pooled cross-section is not the correct specification of the model since there are significant differences across firms. Individual shocks should be taken into account with a panel data estimation.

The Hausman specification test, also available on request, is then performed to investigate the correlation between the unobserved individual effect and the observed explanatory variables. We always reject the null hypothesis; therefore, the correct specification of our model-in a static context and without dealing with the endogeneity problem-would be a Fixed Effect specification.

Moreover, the $\mathrm{F}$ test on the time dummies variables allows us to reject the hypothesis that all the coefficients are jointly equal to zero; therefore, also time fixed effects would be explicitly considered in a fixed effect model specification. However, as it is known, fixed effects in panel data model allow us to solve the omitted variable problem by controlling for the unobservable individual effect but the endogeneity problem is still present. Endogeneity could be produced by several factors like systematic shocks (period effects), omitted variables (unobserved heterogeneity), simultaneity, measurement error. Today, for example, intangible assets drive cash flow and are the primary source of risk. Moreover, because of potential simultaneity, one could think that the intangible assets can also influence firms' access to finance. Some studies, for example, explicitly explore the use of intangible assets as loan collateral and their role in reducing financing frictions in the credit market (Loumioti, 2012).

Therefore, the firms' external and internal finance, as well as the other potential endogenous explanatory variables, could be determined jointly with the dependent variable. Under endogeneity, the FE-estimator will be biased. The traditional approach to solve the endogeneity problem consists in instrumental variables regression with external instruments and fixed or random effects estimators. An alternative approach to tackle the endogeneity issue uses internal instruments by exploiting panel data structure. More specifically, we use a Generalized Method of Moment (GMM) estimator (Arellano \& Bond 1991; Blundell \& Bond 1998) treating all explanatory variables as potentially endogenous. Thus, we rewrite Eq.1 in dynamics terms, as follows:

$$
I A_{i t}=\beta_{0}+\beta_{1} I A_{i, t-1}+\beta_{2} E X T F_{i t}+\beta_{3} I N T F_{i t}+\beta_{4} I N T E R_{i t}+\beta_{5} \operatorname{Size}_{i t}+\beta_{6} A g e_{i t}+\beta_{7} W_{i t}+\gamma_{t}+u_{i}+\varepsilon_{i t}
$$

Equation 4 is a dynamic panel model with fixed effects $\left(u_{i}\right)$ and a lagged dependent variable which allows us to take into account the dynamic nature of the innovative activity. It can be properly estimated through the first differences GMM (GMM-DIFF) estimator proposed by Arellano and Bond (1991) which uses all the available lags of each independent variable in levels as instruments. However, the levels are poor instruments when variables exhibit strong persistence, as in the analyzed model (weak instruments). For this reason, we employ the estimation of the system of equations (GMM-SYS) implemented by Blundell and Bond (1998). It combines the first differenced regression used in GMM-DIFF and the Eq.2 in levels, whose instruments are the lagged differences of the endogenous variables. 
A dynamic GMM-System specification of the model has also been used in previous works on finance and innovation (Himmelberg \& Petersen, 1994; Bloch, 2005; Brown \& Petersen, 2009). Note that, in this analysis, the coefficient of the lagged dependent variable is always significant with a positive sign, showing the opportunity of the dynamic specification of the model.

All the tables show the empirical results and some specification tests. We report the results of the tests proposed by Arellano and Bond (1991) to detect first and second-order serial correlation in the residuals. Note that if $\varepsilon_{\mathrm{it}}$ are not serially correlated, the differenced residuals should show autocorrelation of first-order and absence of second-order serial correlation. As it is shown, the absence of second-order serial correlation, which is a necessary condition for the validity of the instruments, is satisfied in our analysis.

A second specification test is a test of overidentifying restrictions. Since $p>0.05$, the null that the population moment conditions are correct is not rejected, therefore overidentifying restrictions are valid.

To sum up, our test statistics hint at a proper specification of our model allowing us to interpret and comment single coefficients of each model specification.

Given all the previous considerations, the following comments are mainly based on GMM-System estimates.

By focusing on Italy as a whole, the empirical evidence shows that both source of finance are significant in explaining intangible capital. However, external finance would enter with positive sign, while internal finance would enter negatively (Table 5, p. 1). The interaction term enters significantly with positive sign suggesting a complementary effect on intangible assets between the two sources of finance at the aggregate level. When we split the sample between large companies and SMEs, the results show that the interaction term enters significantly with positive sign for small and medium enterprises, which represents the largest sub-sample of the analysis, while it is not significant when large Italian manufacturing firms are considered.

Table 5. Finance and intangibles - Italy (2003-2010), GMM system

\begin{tabular}{llll}
\hline Dependent variable: $\mathrm{IA}_{\text {it }}$ & & & \\
& All Firms & LARGE & SMESs \\
& $(1)$ & $(2)$ & $(3)$ \\
\hline $\mathrm{IA}_{\text {it- } 1}$ & $0.817^{* * *}$ & $0.848^{* * *}$ & $0.818^{* * *}$ \\
$\mathrm{EXTF}_{\text {it }}$ & $(0.006)$ & $(0.032)$ & $(0.006)$ \\
& $0.269^{* * *}$ & 0.048 & $0.285^{* * *}$ \\
$\mathrm{INTF}_{\text {it }}$ & $(0.053)$ & $(0.152)$ & $(0.056)$ \\
& $-0.064^{* *}$ & 0.056 & -0.052 \\
$\mathrm{INTER}_{\text {it }}$ & $(0.031)$ & $(0.021)$ & $(0.008)$ \\
& $0.014^{* *}$ & -0.006 & $0.018^{* *}$ \\
Size & $(0.008)$ & $(0.021)$ & $(0.008)$ \\
& $-0.200^{* * *}$ & 0.014 & $-0.222^{* * *}$ \\
$\mathrm{Age}_{\text {it }}$ & $(0.036)$ & $(0.123)$ & $(0.038)$ \\
& $0.112^{* *}$ & $0.270^{*}$ & $0.124^{* *}$ \\
Industry and Regional controls & $(0.054)$ & $(0.202)$ & $(0.052)$ \\
\hline constant & included & included & included \\
& $-5.18^{*}$ & -4.135 & -4.025 \\
Wald test & $(2.709)$ & $(8.644)$ & $(2.822)$ \\
Sargan test $(p$ value $)$ & $21998.62 * * *$ & $1426.33^{* * *}$ & $20913.90^{* * *}$ \\
$\mathrm{AR}(1)(p$ value $)$ & 0.132 & 0.442 & 0.110 \\
$\mathrm{AR}(2)(p$ value $)$ & 0.000 & 0.000 & 0.000 \\
$\mathrm{~N}$ obs. & 0.143 & 0.334 & 0.122 \\
$\mathrm{R}^{2}$ & 101672 & 4080 & 95899 \\
\hline
\end{tabular}

Note. Coefficients of sectoral and regional controls, unreported to save space, are available on request. All variables are in log. WC-Robust standard errors in parenthesis. Time dummies included but not reported. Significance levels: ${ }^{*} 10 \% ; * * 5 \% ; * * * 1 \%$.

As it is known, the Centre-North and the South of Italy differ in a number of ways, most importantly the higher overall level of economic development and industrialization in the northern part of the country. It is also a commonplace that firms located in Southern regions are riskier, more subject to credit constraints and have less 
access to the capital market (Iazzolino \& Succurro, 2012; Sarno, 2008; Sarno, 2007; Giannola \& Marani, 1991). For this reason, it is interesting to split our sample both by geographic area and by firm size. Table 6 and Table 7 illustrate the main empirical results for Centre-North and South of the country separately.

As it is expected, we find contrasting results depending on the development level of the area. The econometric results show that the impact of external and internal finance on intangible capital can differ sharply between North and South, also driven by the different role played by financial institutions in these two areas of the country.

Specifically, while in the Centre-North external funding is relatively more important in explaining intangible capital for all firms (Table 6, p. 1), in South Italy only self-financing is economically significant at the $1 \%$ level with positive sign (Table 7, p. 1). These findings would suggest that where access to financial markets is easier, that is in the Centre-North of the country, firms mainly rely on external finance for investments in intangible assets. In the Centre-North, indeed, the coefficient of external finance is always higher than that of internal funding. Southern firms, on the contrary, and presumably because of stronger external financial constraints, tend to substitute internal for external resources.

The interaction variable between the two sources of funding gives a relevant contribution for a better interpretation of these results. In particular, the interaction term enters at the $5 \%$ level of significance with positive sign for the manufacturing firms operating in the Centre-North of the country (Table 6, p. 1). This result would indicate some complementary effect between external and internal sources of funding in those regions characterized by a more developed capital market and less financial constraints. Similar results hold when we consider small and medium enterprises in the Centre-North of the country (Table 6, p. 3).

The interaction term enters negatively and significantly at the $5 \%$ level for manufacturing firms operating in southern regions (Table 7, reg.1). When the access to external finance decreases, the effect of internal finance on the investment in intangible assets increases. In other words, firms characterized by weak access to external finance tend to answer by increasing internal financing of intangible assets. Thus, the effect of internal finance on intangible investment increases where the access to external finance decreases, suggesting a certain degree of substitution between the two financial channels.

Similar results hold when we consider only small and medium enterprises in southern regions (Table 7, p. 3). We find that small and medium enterprises, more frequently characterized by limited access to external financial resources, react by increasing internal financing of intangible activities.

Note that, surprisingly, neither internal nor external finance seems to be significant in determining the intangible capital of large companies both in Centre-Northern (Table 6, p. 2) and in Southern Italy (Table 7, p. 2). This raises the question whether financial channels other than those considered in this research are relevant in determining intangible assets investment made by larger manufacturing companies.

With reference to additional firm-level controls, size is usually significant at the $1 \%$ level with negative sign, independently of the geographical location of the firm. This result suggests that smaller firms would have greater knowledge-based capacity than the bigger ones. This is not surprising considered the increasing number of small-sized high-tech start-ups in the country over recent years.

As to firm age, the results for the two parts of the country are sharply contrasting. Age enters at the $1 \%$ level of significance and with positive sign for firms operating in the Centre-North, suggesting that the problems of asymmetric information may be less severe for older firms enjoying relationship banking. We can expect that young firms, on the contrary, have still to establish such a relationship (Petersen \& Rajan, 1995; Berger \& Udell, 2002). Age is not significant in explaining intangible capital in South Italy.

In summary, the empirical evidence on the relationship between external funding, internal funding and innovation is heterogeneous, depending on firms' location and size. Some of these somewhat unexpected results could not have been obtained without the possibility of constructing a large and long panel dataset to control for endogeneity. 
Table 6. Finance and intangibles - centre-north (2003-2010), GMM system

\begin{tabular}{|c|c|c|c|}
\hline Dependent variable: $\mathrm{IA}_{\mathrm{it}}$ & $\begin{array}{c}\text { All Firms } \\
\text { (1) }\end{array}$ & $\begin{array}{l}\text { LARGE } \\
\text { (2) }\end{array}$ & $\begin{array}{c}\text { SMESs } \\
\text { (3) }\end{array}$ \\
\hline $\mathrm{IA}_{\mathrm{it}-1}$ & $\begin{array}{c}0.817 * * * \\
(0.007)\end{array}$ & $\begin{array}{c}0.849 * * * \\
(0.032)\end{array}$ & $\begin{array}{c}0.805^{* * *} \\
(0.007)\end{array}$ \\
\hline EXTF $_{\text {it }}$ & $\begin{array}{c}0.204 * * * \\
(0.053)\end{array}$ & $\begin{array}{c}0.133 \\
(0.141)\end{array}$ & $\begin{array}{c}0.229 * * * \\
(0.056)\end{array}$ \\
\hline $\mathrm{INTF}_{\text {it }}$ & $\begin{array}{c}-0.079 * * \\
(0.031)\end{array}$ & $\begin{array}{c}0.040 \\
(0.081)\end{array}$ & $\begin{array}{c}-0.061 * * \\
(0.032)\end{array}$ \\
\hline INTER $_{\text {it }}$ & $\begin{array}{c}0.013 * * \\
(0.006)\end{array}$ & $\begin{array}{l}-0.007 \\
(0.020)\end{array}$ & $\begin{array}{l}0.012^{* *} \\
(0.008)\end{array}$ \\
\hline Size $_{\text {it }}$ & $\begin{array}{c}-0.160 * * * \\
(0.036)\end{array}$ & $\begin{array}{c}0.054 \\
(0.126)\end{array}$ & $\begin{array}{c}-0.188 * * * \\
(0.039)\end{array}$ \\
\hline Age $_{\text {it }}$ & $\begin{array}{c}0.113^{* *} \\
(0.052) \\
\end{array}$ & $\begin{array}{l}0.347^{* *} \\
(0.148)\end{array}$ & $\begin{array}{c}0.139 * * \\
(0.053)\end{array}$ \\
\hline Industry and Regional controls & included & included & included \\
\hline constant & $\begin{array}{c}-9.884^{* * *} \\
(3.028)\end{array}$ & $\begin{array}{l}-9.672 \\
(9.170)\end{array}$ & $\begin{array}{c}-8.839 * * * \\
(3.190)\end{array}$ \\
\hline Wald test & $21097.09 * * *$ & $1338.02 * * *$ & $19936.52^{* * *}$ \\
\hline Sargan test ( $p$ value) & 0.152 & 0.465 & 0.100 \\
\hline $\operatorname{AR}(1)$ ( $p$ value $)$ & 0.000 & 0.000 & 0.000 \\
\hline $\operatorname{AR}(2)$ ( $p$ value $)$ & 0.163 & 0.323 & 0.127 \\
\hline $\mathrm{N}$ obs. & 93324 & 3933 & 87798 \\
\hline $\mathrm{R}^{2}$ & 0.21 & 0.20 & 0.21 \\
\hline
\end{tabular}

Note. Coefficients of sectoral and regional controls, unreported to save space, are available on request. All variables are in log. WC-Robust standard errors in parenthesis. Time dummies included but not reported. Significance levels: $* 10 \% ; * * 5 \% ; * * * 1 \%$.

Table 7. Finance and intangibles - south (2003-2010), GMM system

\begin{tabular}{lccc}
\hline Dependent variable: $\mathrm{IA}_{\text {it }}$ & All Firms & LARGE & SMESs \\
& $(1)$ & $(2)$ & $(3)$ \\
\hline $\mathrm{IA}_{\text {it-1 }}$ & $0.863^{* * *}$ & 0.920 & $0.863^{* * *}$ \\
& $(0.022)$ & $(1.044)$ & $(0.022)$ \\
$\mathrm{EXTF}_{\text {it }}$ & 0.312 & 2.542 & 0.602 \\
& $(0.766)$ & $(10.675)$ & $(0.051)$ \\
$\mathrm{INTF}_{\text {it }}$ & $0.094^{* * *}$ & 0.803 & $0.712^{* *}$ \\
& $(0.268)$ & $(4.799)$ & $(0.883)$ \\
$\mathrm{INTER}_{\text {it }}$ & $-0.040^{* *}$ & 0.902 & $-0.166^{*}$ \\
& $(0.226)$ & $(3.711)$ & $(0.264)$ \\
Size & $-0.449^{* * *}$ & -0.697 & $-0.459^{* * *}$ \\
& $(0.126)$ & $(1.280)$ & $(0.128)$ \\
$\mathrm{Age}_{\text {it }}$ & -0.014 & 0.044 & -0.083 \\
& $(0.178)$ & $(2.140)$ & $(0.189)$ \\
\hline Industry and Regional controls & included & included & included \\
\hline constant & $-16.25^{* *}$ & -4.589 & $-22.218^{* *}$ \\
& $(10.43)$ & $(11.529)$ & $(11.242)$ \\
Wald test & $2316.16^{* * *}$ & $32.01 * * *$ & $2295.32 * * *$ \\
Sargan test $(p$ value $)$ & 0.152 & 0.941 & 0.077 \\
$\mathrm{AR}(1)(p$ value $)$ & 0.000 & 0.000 & 0.000 \\
$\mathrm{AR}(2)(p$ value $)$ & 0.873 & 0.186 & 0.529 \\
$\mathrm{~N}$ obs. & 8348 & 147 & 8101 \\
$\mathrm{R}^{2}$ & 0.22 & 0.24 & 0.20 \\
\hline
\end{tabular}

Note. Coefficients of sectoral and regional controls, unreported to save space, are available on request. All variables are in log. WC-Robust standard errors in parenthesis. Time dummies included but not reported. Significance levels: * $10 \%$; **5\%; ***1\%. 


\section{Discussion}

This paper assesses how intangible capital depends on the various sources of finance and whether it varies across the Italian regions by focusing on manufacturing firms over the 2003-2010 period.

The empirical evidence suggests that the relative importance of the two channels depends on firms' size and differs significantly between the two major parts of Italy. In the Centre-North, where access to financial markets is easier, firms would mainly use external finance to fund intangible capital, while in South Italy, where access to external finance is more constrained, they would mainly rely on internal funding. The empirical findings show that in the Centre-Northern regions external funding is the most important channel explaining intangible capital; in Southern regions, on the contrary, only self-financing is economically significant in explaining the ratio between intangible assets and total assets.

The empirical evidence on the interaction term would also indicate some complementary effect between external and internal sources of funding in the Centre-North of the country, characterized by a more developed capital market and less financial constraints. In the Mezzogiorno of Italy, on the contrary, data would suggest a substitution effect between the two financial channels. When the access to external finance decreases, the effect of internal finance on the investment in intangible assets increases. In other words, firms characterized by weak access to external finance tend to answer by increasing internal financing of intangible assets.

To summarize, empirical evidence would suggest that below a certain level of per-capita GDP a substitution effect prevails between the two sources of finance. On the contrary, some complementary effect between external and internal finance would exist in more developed Italian regions.

As future research, this study suggests to assess whether some empirical results may depend on financial factors external to the firm, such as sector or public incentives which could be a decisive source of finance and they should be explicitly considered in future analysis. This research development would also help to identify a range of public policy instruments that could promote private sector investment in, and better utilization of, intangible assets.

\section{References}

Aiello, F., \& Cardamone, P. (2012). Regional economic divide and the role of technological spillovers in Italy. Evidence from microdata. Structural Change and Economic Dynamics, 23, 205-220. http://dx.doi.org/10.1016/j.strueco.2012.03.001

Aiello, F., \& Scoppa, V. (2000). Uneven Regional Development in Italy: Explaining Differences in Productivity Levels. Giornale degli Economisti e Annali di Economia, 60, 270-298.

Arellano, M., \& Bond, S. (1991). Some tests of specification for panel data: Monte Carlo evidence and an application to employment equations. Review of Economic Studies, 58, 277-297. http://dx.doi.org/10.2307/2297968

Arrow, K. (1962). Economic Welfare and the Allocation of Resources for Invention. In R. Nelson (Ed.), The Rate and Direction of Inventive Activity.

Atzeni, G., \& Carboni, O. (2006). Regional Disparity in ICT Adoption: an Empirical Evaluation of The Effects of Subsidies in Italy. Crenos Working paper n.8, University of Cagliari and Sassari.

Benfratello, L., Schiantarelli, F., \& Sembenelli, A. (2008). Banks and innovation: Microeconometric evidence on Italian firms. Journal of Financial Economics, 90, 197-217. http://dx.doi.org/10.1016/j.jfineco.2008.01.001

Berger, A., \& Udell, G. (2002). Small Business Credit Availability and Relationship Lending: The Importance of Bank Organizational Structure. Economic Journal, 112, 32-53. http://dx.doi.org/10.1111/1468-0297.00682

Bianchi, C., \& Menegatti, M. (1997). Differenziali regionali di produttività e crescita economica: un riesame della convergenza in Italia nel periodo 1970-1994. Studi Economici, 52(63), 15-42.

Bigoni, M., Bortolotti, S., Casari, M., Gambetta, D., \& Pancotto, F. (2013). Cooperation Hidden Frontiers: The Behavioral Foundations of the Italian North-South Divide. Quaderni - Working Paper DSE n.882, University of Bologna. http://dx.doi.org/10.6092/unibo/amsacta/3690

Bloch, C. (2005). R\&D investment and internal finance: the cash flow effect. Economics of Innovation and New Technology, 14(3), 213-223. http://dx.doi.org/10.1080/1043859042000312710

Blundell, R., \& Bond, S. (1998). Initial conditions and moment restrictions in dynamic panel data models. Journal of Econometrics, 87, 115-143. http://dx.doi.org/10.1016/S0304-4076(98)00009-8 
Brown, J. R., \& Petersen, B. C. (2009). Why has the investment-cash flow sensitivity declined so sharply? Rising R\&D and equity market developments. Journal of Banking and Finance, 33, 971-984. http://dx.doi.org/10.1016/j.jbankfin.2008.10.009

Brown, J. R., Fazzari, S. M., \& Petersen, B. C. (2009). Financing Innovation and Growth: Cash Flow, External Equity, and the 1990s R\&D Boom. Journal of Finance, 64(1), 151-186. http://dx.doi.org/10.1111/j.1540-6261.2008.01431.x

Carmeci, G., \& Mauro, L. (2002). The Convergence of the Italian Regions and Unemployment: Theory and Evidence. Journal of Regional Science, 42(3), 509-532. http://dx.doi.org/10.1111/1467-9787.00269

Corrado, C. A., Hulten, C. R., \& Sichel, D. E. (2006). Intangible Capital and Economic Growth. NBER Working Paper No. 11948. Retrieved from http://www.nber.org/papers/w11948.pdf

Corrado, C. A., Hulten, C. R., \& Sichel, D. E. (2009). Intangible Capital and U.S. Economic Growth. Review of Income and Wealth, 85, 661-685. http://dx.doi.org/10.1111/j.1475-4991.2009.00343.x

Czarnitzki, D., \& Hottenrott, H. (2011). R\&D Investment and Financing Constraints of Small and Medium-Sized Firms. Small Business Economics, 36(1), 65-83. http://dx.doi.org/10.1007/s11187-009-9189-3

De Stefanis, S., \& Sena, V. (2005). Public capital and total factor productivity: New evidence from the Italian regions, 1970-98. Regional Studies, 39(5), 603-617. http://dx.doi.org/10.1080/00343400500151863

Di Giacinto, V., \& Nuzzo, G. (2006). Explaining labour productivity differentials across Italian regions: the role of socio-economic structure and factor endowments. Papers in Regional Science, 85, 299-320. http://dx.doi.org/10.1111/j.1435-5957.2006.00072.x

Di Liberto, A., Pigliaru, F., \& Mura, R. (2008). How to measure the unobservable: a panel technique for the analysis of TFP convergence. Oxford Economic Papers, 60(2), 343-368. http://dx.doi.org/10.1093/oep/gpm022

Evangelista, R., Iammarino, S., Mastrostefano, V., \& Silvani, A. (2002). Looking for Regional Systems of Innovation: Evidence from the Italian Innovation Survey. Regional Studies, 36(2), 173-186. http://dx.doi.org/10.1080/00343400220121963

Fabiani, S., \& Pellegrini, G. (1997). Education, infrastructure, geography and growth: an empirical analysis of the development of Italian provinces. Discussion Paper n.323, Bank of Italy, Rome.

Feldman, M., \& Kogler, D. (2010). Stylized facts in the geography of innovation. In B. Hall \& N. Rosenberg (Eds.), Handbook of Economics of Innovation (pp. 381-410). Amsterdam, North Holland. http://dx.doi.org/10.1016/S0169-7218(10)01008-7

Giannola, A., \& Marani, U. (1991). La struttura finanziaria delle imprese industriali meridionali. Meridiana, 1112.

Giudici, G., \& Paleari, S. (2000). The Provision of Finance to Innovation: A Survey Conducted among Italian Technology-based Small Firms. Small Business Economics, 14, 37-53. http://dx.doi.org/10.1023/A:1008187416389

Guiso, L., Sapienza, P., \& Zingales, L. (2004). Does local financial development matter? Quarterly Journal of Economics, 119, 929-969. http://dx.doi.org/10.1162/0033553041502162

Hall, B. (1990). The Impact of Corporate Restructuring on Industrial Research and Development. Brooking Papers on Economic Activity, 1, 85-136. http://dx.doi.org/10.2307/2534781

Hall, B. (1992). Investment and Research and Development at the Firm Level: Does the Source of Financing Matter? NBER Working Paper 4096. Retrieved from http://www.nber.org/papers/w4096

Herrera, A., \& Minetti, R. (2007). Informed finance and technological change: evidence from credit relationships. Journal of Financial Economics, 83, 223-269. http://dx.doi.org/10.1016/j.jfineco.2005.12.001

Himmelberg, C., \& Petersen, B. (1994). R\&D and Internal Finance: A Panel Study of Small Firms in High-Tech Industries. Review of Economics and Statistics, 76, 38-51. http://dx.doi.org/10.2307/2109824

Holthausen, R., \& Watts, R. (2001). The relevance of the value-relevance literature for financial accounting standard setting. Journal of Accounting \& Economics, 31(1-3), 3-75. http://dx.doi.org/10.1016/S0165-4101(01)00029-5

Iammarino, S., Sanna-Randaccio, F., \& Savona, M. (2009). The perception of obstacles to innovation. Foreign multinationals and domestic firms in Italy. Revue D'économie Industrielle, 125, 75-104. 
http://dx.doi.org/10.4000/rei.3953

Iazzolino, G., \& Succurro, M. (2012). L'affidabilità finanziaria delle imprese del Mezzogiorno: un'analisi strutturale su micro dati. Rivista Economica del Mezzogiorno, 26(3), 463-489.

Lev, B. (2001). Intangibles: Management, Measurement, and Reporting. Washington, D.C.: Brookings Institution Press.

Loumioti, M. (2012). The Use of Intangible Assets as Loan Collateral. Working paper, University of Southern California.

Maffezzoli, M. (2006). Convergence Across Italian Regions and the Role of Technological Catch-Up. The B.E. Journal of Macroeconomics, 6(1), 1-43.

Marrocu, E., Paci, R., \& Pontis, M. (2011). Intangible capital and firms' productivity. Industrial and Corporate Change, 21(2), 377-402. http://dx.doi: 10.1093/icc/dtr042

Nakamura, L. (2001). Investing in Intangibles: Is a Trillion Dollars Missing from GDP? Business Review, 4, 2737.

National Research Council. (2009). Intangible Assets: Measuring and Enhancing Their Contribution to Corporate Value and Economic Growth: Summary of a Workshop. Washington, DC: The National Academies Press.

Nelson, R. (1959). The Simple Economics of Basic Scientific Research. Journal of Political Economy, 49, 297306. http://dx.doi.org/10.1086/258177

Paci, R., \& Pigliaru, F. (1995). Differenziali di crescita tra le regioni italiane: un'analisi cross-section. Rivista di Politica Economica, 10, 3-34.

Paci, R., \& Saba, A. (1998). The empirics of regional economic growth in Italy. 1951-1993. Rivista Internazionale di Scienze Economiche e Commerciali, 45, 515-542.

Petersen, M., \& Rajan, R. (1995). The Effect of Credit Market Competition on Lending Relationships: Evidence from Small Business Data. Journal of Finance, 49, 37. http://dx.doi.org/10.1111/j.1540-6261.1994.tb04418.x

Sarno, D. (2007). Status finanziario delle imprese e struttura industriale: il caso del Mezzogiorno. Rivista Economica Del Mezzogiorno, 21, 751-777.

Sarno, D. (2008). Capital structure and growth of the firms in the backward regions of the south Italy. Applied Financial Economics, 18(10), 821-833. http://dx.doi.org/10.1080/09603100701222309

Shleifer, A., \& Vishny, R. (1992). Liquidation Values and Debt Capacity: A Market Equilibrium Approach. Journal of Finance, 47(4), 1343-1366. http://dx.doi.org/10.1111/j.1540-6261.1992.tb04661.x

Siegel, P. H., \& Borgia, C. (2007). The Measurement and Recognition of Intangible Assets. Journal of Business and Public Affairs, 1(1).

Stolowy, H., \& Jeny-Cazavan, A. (2001). International Accounting Disharmony: The Case of Intangibles. Accounting, Auditing \& Accountability Journal, $477-497$. http://dx.doi.org/10.1108/09513570110403470

Ughetto, E. (2008). Does internal finance matter for R\&D? New evidence from a panel of Italian Firms. Cambridge Journal of Economics, 32(6), 907-925. http://dx.doi.org/10.1093/cje/ben015

Williamson, O. E. (1988). Corporate finance and corporate governance. Journal of Finance, 43, 567-592. http://dx.doi.org/10.1111/j.1540-6261.1988.tb04592.x

Wyatt, A. (2005). Accounting recognition of intangible assets: theory and evidence on economic determinants. Accounting Review, 80, 967-1003. http://dx.doi.org/10.2308/accr.2005.80.3.967

\section{Notes}

Note 1. It would be desirable to test a second degree polynomial (EXTF*INTF) ${ }^{2}$, giving information on the optimum level of internal finance. However, because of the interaction variable construction, the first degree (EXTF*INTF) would be dropped by Stata because of (perfect) collinearity. Therefore, the second degree polynomial is separately tested and the empirical results are available on request.

Note 2. In order to measure the size of a firm, different variables could be used like the number of employees, total assets and turnover. The accounting data on "turnover" are more reliable than those on 
total number of employees and there are less missing data; moreover, differently from total assets, the "turnover" variable allows to classify the firms and split the sample according to the European Union classification.

\section{Copyrights}

Copyright for this article is retained by the author(s), with first publication rights granted to the journal.

This is an open-access article distributed under the terms and conditions of the Creative Commons Attribution license (http://creativecommons.org/licenses/by/3.0/). 